\title{
Copper Oxide Nanostructures; Syntheses and Characterization
}

\author{
Sariya D.AL. ALgawi \\ Department of Applied Sciences, University of Technology, Baghdad-Iraq.
}

\begin{abstract}
Copper oxide $(\mathrm{CuO})$ nanoparticles are synthesized by pulse laser ablation (Nd:YAG, $\lambda=1 \cdot 7 \leqslant \mathrm{~nm}$,) of cupper $(\mathrm{Cu})$ in pure water (DDDW). The synthesized nanomaterial is characterized with UV-Visible spectroscopy; atomic force microscopy AFM, in combination with FTIR.AFM image shows that the $\mathrm{CuO}$ are spherical in shape with average diameter $01 \mathrm{~nm}$ and FTIR spectrum confirm the formation of $\mathrm{CuO}$ nanoparticles. The UV-vis spectrum of the colloidal nanoparticles shows maximum absorbance around the UV region at $\sim r V \cdot n m$ and in Vis region at $\tau \cdots \mathrm{nm}$, indicating the formation of $\mathrm{CuO}$ nanoparticles with a direct bandgap energy of $\sim r, \mathrm{reV}$.
\end{abstract}

Keywords: laser ablation, Nano particles, Cuonano-particles, nanoparticals.

\section{Introduction}

The oxides of transition metals are an important class of semiconductors, which have applications in magnetic storage media, solar energy transformation, electronics and catalysis $\left[\mathrm{I}^{-} \mathrm{r}\right] \mathrm{CuO}$ is a semiconducting compound with a narrow band gap and used for photoconductive and photothermal applications $[\varepsilon, 0]$. However, the reports on the preparation and characterization of nanocrystalline $\mathrm{CuO}$ are relatively few to some other transition metal oxides such as zinc oxide, titanium dioxide, tin dioxide and iron oxide. Some methods for the preparation of nanocrystalline $\mathrm{CuO}$ have been reported recently such as the sonochemical method [ $\left.{ }^{\top}\right]$, sol-gel technique $[\mathrm{V}]$, one-step solid state reaction method at room temperature [^], electrochemical method [9], thermal decomposition of precursors [ $\left[{ }^{\cdot}\right]$ and coimplantation of metal and oxygen ions [11] etc. Laser ablation in liquid media is a 'top down' approach for the synthesis of nanomaterials having desired shape, size and chemical composition and surfaces free from chemical contamination, which are essential for further functionalization of nanomaterials for biological and sensing applications. This technique is adopted by several workers $\left[Y_{-} \mid T^{T}\right]$ for the synthesis of colloidal solution of nanoparticles of different metals and semiconducting materials. Recently, copperbased nanomaterials are of great interest because of their optical, catalytical, mechanical and electrical properties, resulting in a wide range of applications in the field of metallurgy, catalysis, nano and optoelectronics [ ${ }^{\prime}$ ]. CurO (cuprous oxide) and $\mathrm{CuO}$ (cupric oxide) are two important oxide compounds of copper and mostly behave like p-type semiconductor. Cuprous oxide is a II-VI semiconductor having direct bandgap of $\sim \mathrm{r} \mathrm{eV}$, while that of cupric oxide has a monoclinic crystal structure with a bandgap of $1, Y_{1}-1,01$ ev [10]. Copper oxide nanomaterials have lower surface potential barrier than metals, which affects their electron field emission properties, and therefore are highly application as electron sources in cathode ray tube and flat panel display [10].

\section{Experimental}

To produce the copper nanoparticles, a piece of copper metal $(99,99 \%)$ placed at the bottom of glass vessel containing $r \mathrm{ml}$ of double-distilled water was irradiated with the focused output of fundamental wavelength (1. $7 \varepsilon \mathrm{nm}$ ) of $\mathrm{Nd}$ : YAG laser operating at vo. mJ energy with a positive lens having a focal length of $11 . \mathrm{mm}$, was utilized as an ablation source. The number of laser pulsed applied for the metal target 10. pulses and laser energy $v \circ \cdot m J$. Fig.( (1) shows the experimental setup of PLAL system were light green colure colloidal solution was obtained after ablation as shows in Fig. $(r)$. The UVVisible absorption spectra of colloidal solution of nanoparticles so synthesized with double beam spectrophotometer CECIL, C. VY.. (France) with energy band gap $\mathrm{Eg}(\mathrm{eV})$. The average particle size and amount of 
aggregation of NPs were characterized with atomic force microscope (AFM) AA ${ }^{\top}$.. scanning probe microscope Angstrom Advanced Inc. the recording FTIR spectrum, in the wave number region of $\varepsilon \cdots-\varepsilon \cdots \mathrm{cm}^{-1}$.

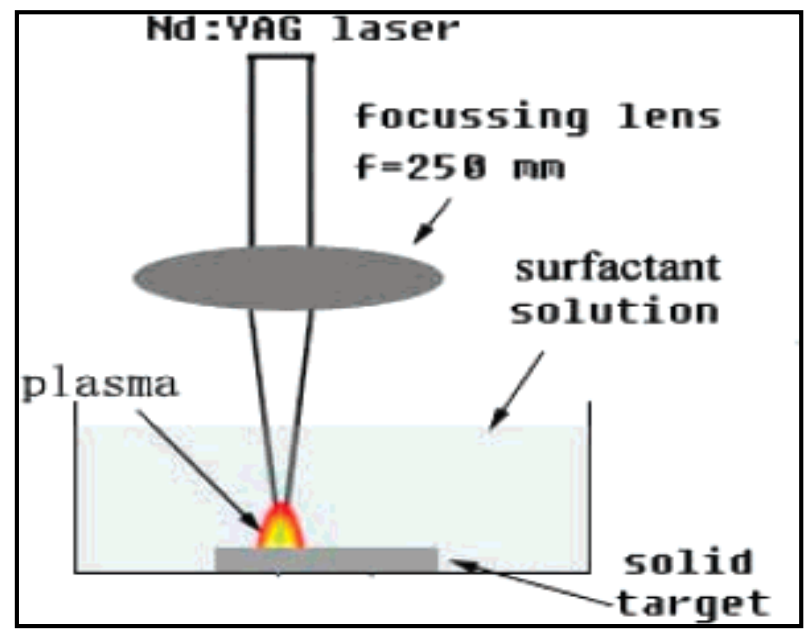

Fig.( ') Typical set-up for pulsed laser ablation in liquid media.

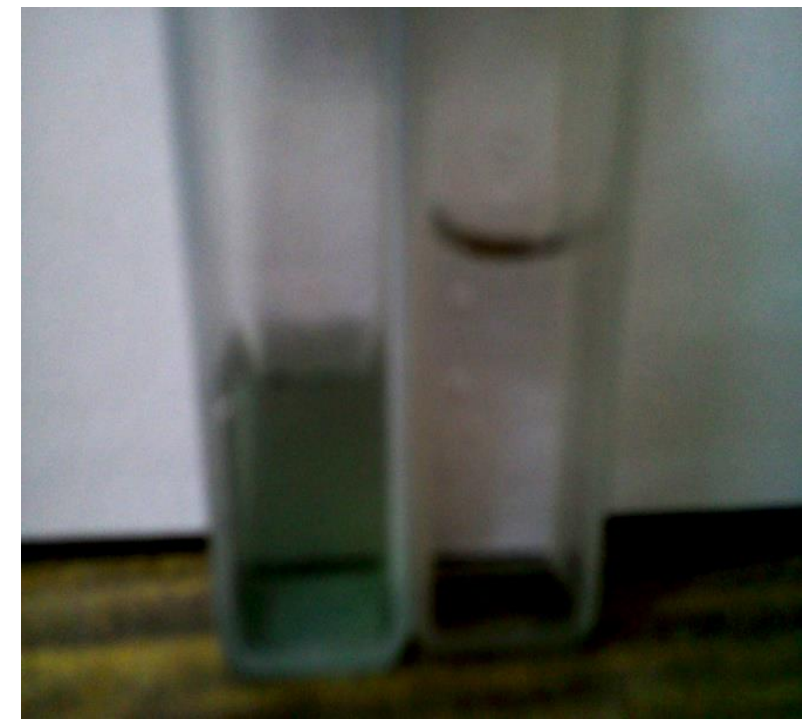

Fig.( ') Photograph of colloidal CuO NPS.

\section{Results and discussion}

The UV-Visible absorption spectrum of the as-synthesized solution of colloidal nanoparticles is recorded in the wavelength region of $r \cdots-q \cdots n$ m. It exhibits an intense peak center at $\sim Y v \cdot n m$ and another peak with low intensity at $\sim 7 \cdot \mathrm{nm}$ as shown in Fig. $\left({ }^{\top}\right)$. The peak at $\sim Y V \cdot n m$ is due to interband transition of copper electron from deep level of valence band while peak at $\sim$ T. nm is due to interband transition of copper electron from upper level of valence band, agreement with reported previously (Curtis et.al)[17]. The optical bandgap of the synthesized nanoparticles is calculated using the Tauc relation (Singh et al $\left.r_{\cdots} \cdot{ }^{9} b\right) \alpha h v=(h v-E g)^{n}$, where $\mathrm{h} v$ is the incident photon energy and $\mathrm{n}$ is the exponent that determines the type of electronic transition causing the absorption and can take the values $I / r, r / r, r$ and $r / r$ $[\mathrm{l}]$. The best linear relationship is obtained by plotting $(\alpha h v)^{r}$ against $h v$, indicating that the optical bandgap of these nanoparticles is due to a direct allowed transition. Tauc plot for as synthesized colloidal nanoparticles is shown in Fig.( $₹)$. The bandgap of as synthesized colloidal nanoparticles is determined from the intercept of the straight line at $\alpha=\cdot$, which is found to be $r, \mathrm{reV}$.

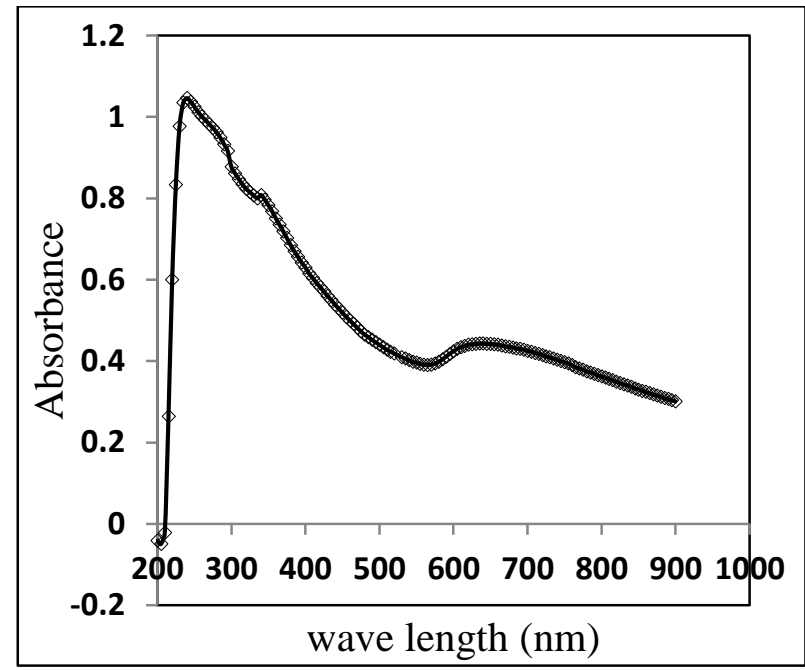

Fig.( ') UV-Visible absorption spectrum of as synthesized colloidal solution of $\mathrm{CuO}$ nanoparticles by laser ablation of copper in water.

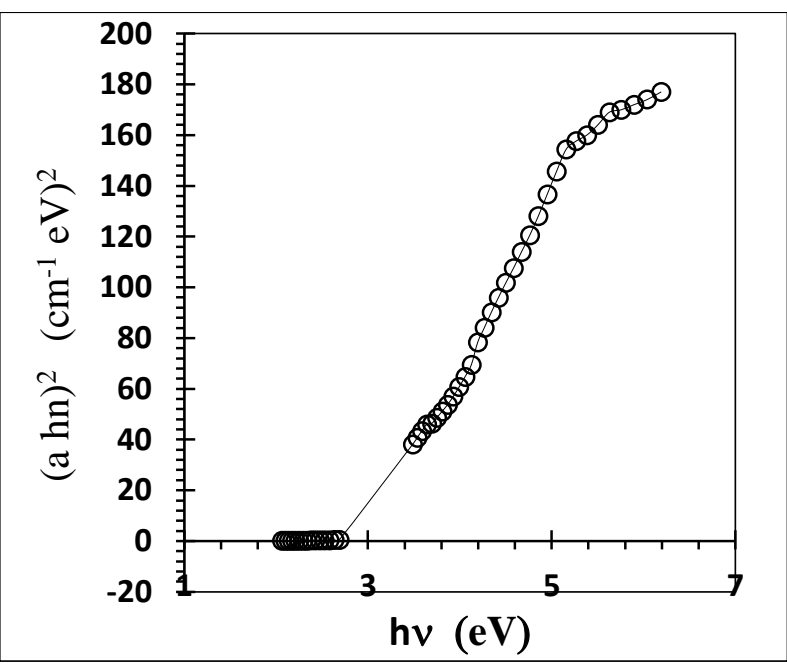

Fig.( ( ) Taucplot of $U V$ Visible absorption data of as synthesized colloidal $\mathrm{CuO}$ 
Journal of Al-Nahrain University Science

nanoparticles for the calculation of bandgap energy.

Fig. ( $\left.{ }^{\circ}\right)$ shows the AFM images and the corresponding size distributions of the copper oxide nanoparticals. It's clear from figure that $\mathrm{CuO}$ nanoparticles are spherical in shape having average diameter of $01 \mathrm{~nm}$ are observed over the entire surface, as shown in the inset. The r-dimensional ( $r \mathrm{D})$ AFM image of material nanopartical in which the irregular and randomly distributed $\mathrm{CuO}$ nanoparticals pillars and voids over the entire surface can be seen with a maximum value of $\checkmark, \wedge \mathrm{r} \mathrm{nm}$ exhibits morphology with a root-mean-square (RMS) roughness of $\cdot, \lambda r \varepsilon n m$.
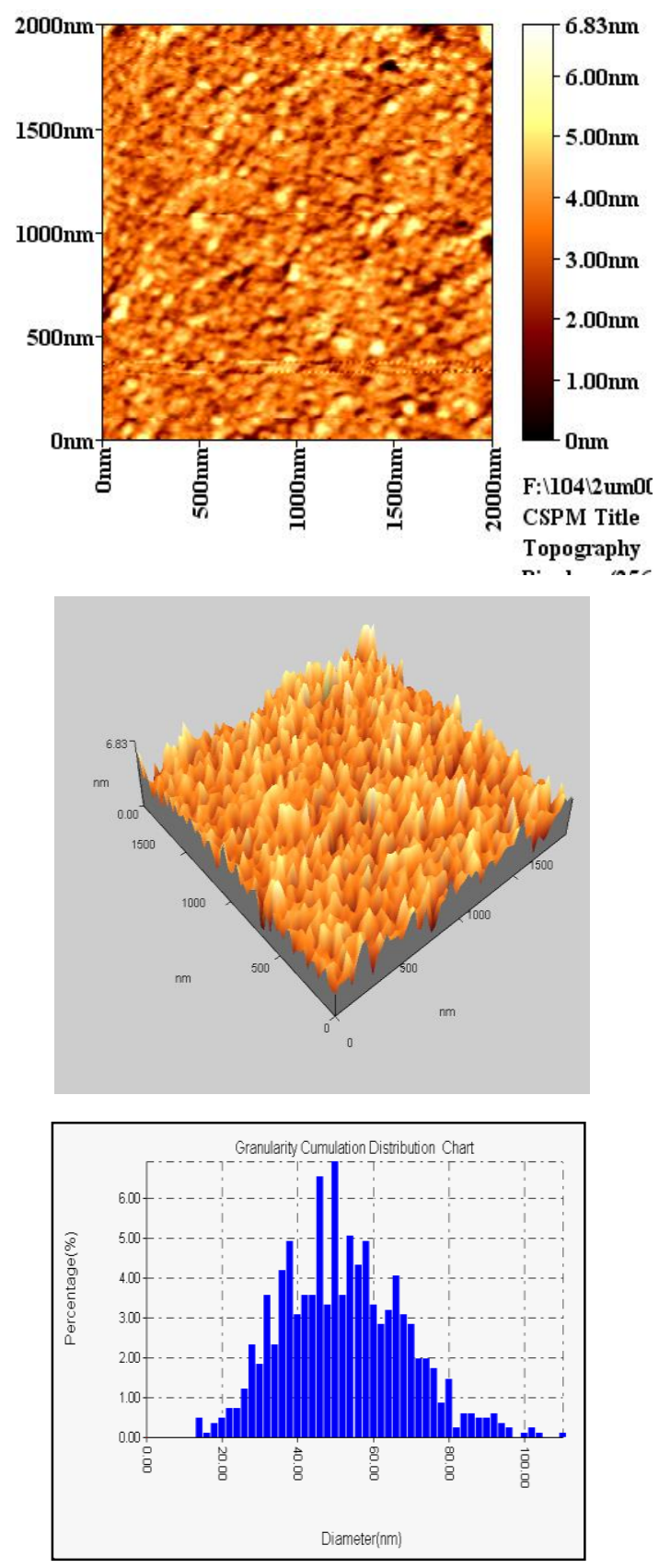

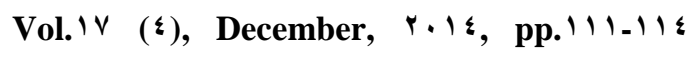

\section{Fig.( (2) AFM image of as prepared $\mathrm{CuO}$ nanoparticles.}

The FTIR spectrum of $\mathrm{CuO}$ nanoparticles is shown in Fig.( ( $\left.{ }^{7}\right)$. An intense and wide peak centered at $r \leqslant \varepsilon \cdot \mathrm{cm}^{-1}$ is assigned as $\mathrm{H}-\mathrm{OH}$ stretching. The peak centered $0 \cdots$ to $710 \mathrm{~cm}^{-1}$ corresponds to the vibrational mode of $\mathrm{Cu}-\mathrm{O}$ in $\mathrm{CurO}$ phase (Heltemes 1974) [1/1]. Therefore, one can conclude that the nanoparticles have cuprous oxide.

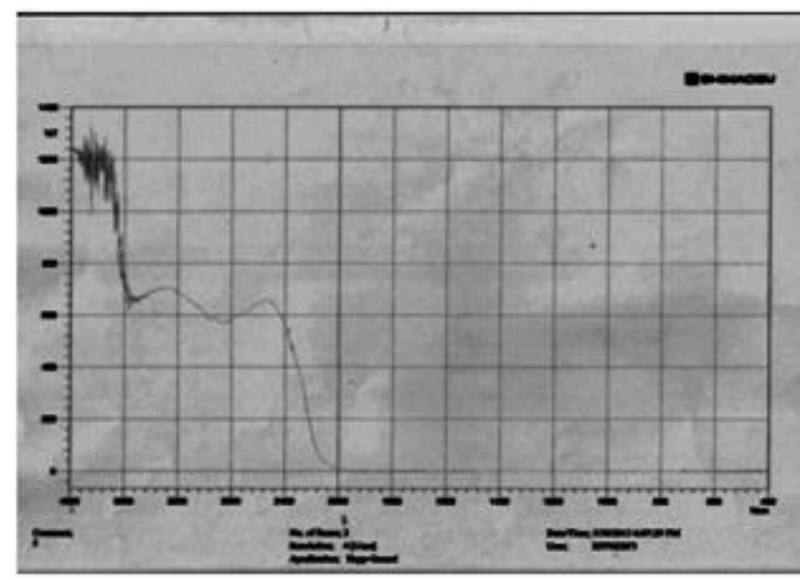

Fig.( () FTIR spectra of the extracted $\mathrm{CuO}$ NPs.

\section{Conclusion}

In this study the film structure and the surface morphology of the deposits materials have been studied using atomic force microscopes (AFM). The UV-VIS spectrum of the colloidal nanoparticles shows maximum absorbance around the UV region at $\sim r V \cdot \mathrm{nm}$ and in Vis region at $\sim \cdots \mathrm{nm}$, indicating the formation of $\mathrm{CuO}$ nanoparticles with a direct bandgap energy of $\sim r \mathrm{eV}$. from the FTIR spectrum of $\mathrm{CuO}$ nanoparticles, the peak centered $0 \ldots$ to $710 \mathrm{~cm}^{-1}$ corresponds to the vibrational mode of $\mathrm{Cu}-\mathrm{O}$ in $\mathrm{Cu} \mathrm{O}$ phase with spherical in shape having average diameter of 0) $\mathrm{nm}$.

\section{References}

['] Lanje A.S, Ningthoujam, R.S., Shrama S.J., Vatsa R.K., Pode,R.B. Int. J. Nanotechnol., $\vee,(q \vee q), r \cdot 1 \cdot$.

$[\ulcorner]$ Wolhfarth E.P.; Ferromagnetic Materials, Vol. II, North-Holland, Amsterdam, New York, Oxford, Tokyo, 19^.

[ץ] Mitsuyu T., Yamakazi O., Ohji K., Wasa K., Ferroelectrics, \& $r$, rrr, ( $9 \wedge \mathrm{r})$. 
[₹] Lee S.,. Choi U.S, S. Li, J.A. Eastman, J. Heat Transfer, I $Y$ ), $Y \wedge \cdot$, ( 1999$)$.

[0] Rakhshni, A.E. Solid State Electron., rq(V), 19人

[`] Kumar R.V, Diamant Y., A. Gedanken, Chem. Mater., IY(Yr.•l), r...

[₹] Eliseev A. A., Lukashin,A.V. Vertegel A. A., Heifets L.I., Zhirov A. I, Tretyakov Y. Mater D., Res. Innov., $r(r \cdot \wedge), r \cdots$.

[^] Xu, J.F. W. Ji, Shen Z.X., Tang S.H., X.R. Ye, D.Z. Jia, X.Q. Xin, J. Solid State Chem. $1 \leqslant \vee(017), Y \cdots$.

[9] Borgohain K., Singh J.B., M.V. Rama Rao, T. Shripathi, S. Mahamuni, Phys. Rev., 71 (1).9r), r...

[l•] J.Q. Yu, Z. Xu, D.Z. Jia, Chin. J., Func. Mater.Instrum., $\left.{ }^{\circ}(Y\urcorner \vee\right), 1999$.

[' '] Nakao S., Ikeyama M, Mizota T, P. Jin, Tazawa M., Miyagawa Y., Miyagawa S., Wang S., Wang L., Rep. Res. Cent. Ion Beam Technol., Hosei Univ. Suppl., IA(10r), r...

[1Y] SWARNKAR R K*, SINGH S C and GOPAL R, Bull. Mater. Sci., Vol. $r \xi$, $r \cdot 11$.

[1T] Lin Y, Skaff H, Emrick T, Dinsmore A D and Russell T P Science r r $r q 9,(Y \cdots r)$.

[ 1 ] Link S, Burda C, Nikoobakht B and ElSayed M A Y... J. Phys. Chem. B I. 7 ) 0 .

[10] Serin N, Serin T, Horzum S and Celik Y r... Semicond. Sci.Tech. r. rq৯ (V)

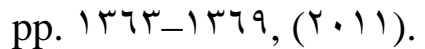

[17] Curtis A C, Duff D G, Edwards P P, Jefferson D A, Johnson B F G, Kirkland A I and Wallace A S 1911 J. Phys. Chem. 9Y rYIl.

[IV] Singh S C, Swarnkar R K and Gopal R Bull. Mater. Sci. $\left.r T(Y), r^{\prime}\right) \cdot$

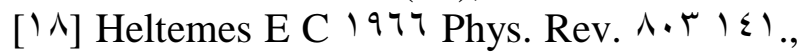
(1974).

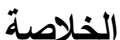

جسيمات ثثائي اوكسيد النحاس CuO النانوية تم تحضيرها بواسطة تشعيع معدن النحاس النقي بليزر النديميوم

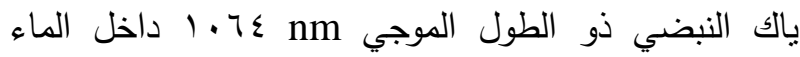
المقطر • نم تشخيص الجسيمات المتولدة بواسطة مطياف

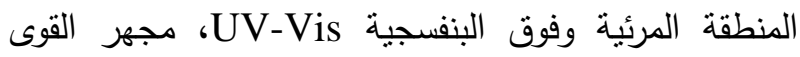
الذرية بالاضافة الى مطياف تحويلات فورير للاشعة تحت الحمراء FTIR. اظهرت صور المجهر الذري جسيمات اوكسيد النحاس النانوية ذات شكل كروي والتي اثتتت بواسطة قياست الـ FTIR. أطياف الامتصاص للعوالق النانوية تظهر قيمة أمتصاص عظمى في المنطقة الفوق بنفسجية عند طول

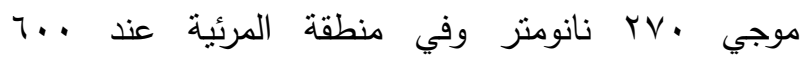
نانومتروالتي تدل على توليد جسيمات CuO النانوية وبفجوة

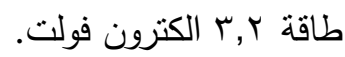

الكلمات المرشدة: القشط بالليزر ، جسيمات اوكسيد النحاس النانوية، الجسيمات النانوية. 
Journal of Al-Nahrain University

Vol.IV (\&), December, Y. I

\section{Science}

